\title{
Factors associated with health dissatisfaction of elementary school teachers
}

\author{
Fatores associados à insatisfação com a saúde de professores do ensino fundamental \\ Factores asociados a la insatisfacción con la salud de los maestros de primaria
}

\section{Ediálida Costa Santos'
ORCID: 0000-0001-7309-0092 \\ Mariano Martínez Espinosa' \\ ORCID: 0000-0002-0461-5673 \\ Samira Reschetti Marcon' \\ ORCID: 0000-0002-5191-3331 \\ Annelita Almeida Oliveira Reiners' ORCID: 0000-0002-5699-8215 \\ Marília Duarte Valim' ORCID: 0000-0002-2746-1865 \\ Bryan Mariano Martínez Alves" ORCID: 0000-0001-6499-6482}

'Universidade Federal de Mato Grosso. Cuiabá, Mato Grosso, Brazil. "Universidade de São Paulo. São Carlos, São Paulo, Brazil.

How to cite this article: Santos EC, Espinosa MM, Marcon SR, Reiners AAO, Valim MD, Alves BMM. Factors associated with health dissatisfaction of elementary school teachers.

Rev Bras Enferm. 2020;73(Suppl 5):e20190832. doi: http://dx.doi.org/10.1590/0034-7167-2019-0832

\section{Corresponding author:}

Ediálida Costa Santos

E-mail:enf.edialida@gmail.com

EDITOR IN CHIEF: Antonio José de Almeida Filho ASSOCIATE EDITOR: Hugo Fernandes

Submission: 11-25-2019
Approval: 07-05-2020

\begin{abstract}
Objective: To evaluate factors associated with health dissatisfaction of public elementary school teachers. Methods: Cross-sectional study conducted among teachers from a Midwest capital, in 2017. A self-administered questionnaire composed of a collection of validated instruments and additional questions was used. Poisson Regression was performed, considering significance $p<0.05$. Results: sample composed of 326 teachers, with an average age of 43 years, $87.1 \%$ female. Concerning health conditions, $19.5 \%$ were dissatisfied and $31.5 \%$ were indifferent. In a simultaneous analysis of the factors of interest, a statistically significant association was found among teacher's health dissatisfaction and the presence of symptoms of common mental disorders $(\mathrm{PRa}=2.28)$, musculoskeletal symptoms in the last 12 months $(P R a=1.71)$, voice disorders $(P R a=1.29)$, never/rarely waking up rested $(P R a=1.45)$, never/ rarely engage in physical activity/sports $(\mathrm{PRa}=1.57)$, among other factors. Conclusion: never/rarely waking up rested and engaging in physical activity/sports, the presence of common mental disorders, musculoskeletal symptoms and voice disorders were associated with health dissatisfaction.

Descriptors: Prevalence; Occupational Health; School Teachers; Quality of Life; Health.
\end{abstract}

\section{RESUMO}

Objetivo: Avaliar os fatores associados à insatisfação com a saúde em professores do ensino fundamental da rede pública. Métodos: Estudo transversal realizado com professores de uma capital do Centro-Oeste, em 2017. Utilizou-se questionário autoaplicável, composto por compilado de instrumentos validados e questões adicionais. Realizada regressão múltipla de Poisson, considerando significância $p<0,05$. Resultados: amostra composta por 326 professores, com idade média de 43 anos e $87,1 \%$ sexo feminino. Quanto à saúde, 19,5\% estavam insatisfeitos e 31,5\% indiferentes. Em análise simultânea dos fatores de interesse, observou-se associação entre insatisfação com a saúde estatisticamente significante, com a presença de sintomas de transtornos mentais comuns $(R P=2,28)$, sintomas osteomuscular nos 12 últimos meses $\left(\mathrm{RP}_{\mathrm{a}}=1,71\right)$, distúrbios de $\mathrm{voz}\left(\mathrm{RP}_{\mathrm{a}}=1,29\right)$, nunca/raramente acordar descansado ( $R P=1,45)$, nunca/raramente realizar atividade física/esportes $(R P=1,57)$, entre outros fatores. Conclusão: nunca/raramente acordar descansado e realizar atividade física/ esportes, a presença de transtornos mentais comuns, sintomas osteomuscular e distúrbios de voz, estiveram associados à insatisfação com a saúde.

Descritores: Prevalência; Saúde do Trabalhador; Professores Escolares; Qualidade de Vida; Saúde.

\section{RESUMEN}

Objetivo: Evaluar los factores asociados a la insatisfacción con la salud en los maestros de escuela primaria de la red pública Métodos: Se trata de un estudio transversal realizado entre profesores de una capital del Centro-Oeste de Brasil en 2017. Se utilizó un cuestionario auto administrado que consistía en una compilación de instrumentos validados y preguntas adicionales. Se realizó la regresión de Poisson, considerando la significación $p<0,05$. Resultados: La muestra estaba compuesta por 326 maestros, con edad media de 43 años y el $87,1 \%$ del sexo femenino. En cuanto a la salud, el 19,5\% estaba insatisfecho y el 31,5\%, indiferente. En un análisis simultáneo de los factores de interés, se observó una asociación estadísticamente significativa entre la insatisfacción con la salud y la presencia de síntomas de trastornos mentales comunes $(\mathrm{RPa}=2,28)$, síntomas osteomusculares en los últimos 12 meses $(\mathrm{RPa}=1,71)$, trastornos de la voz $(\mathrm{RPa}=1,29)$, nunca/raramente despertarse descansado ( $\mathrm{RPa}=1,45)$, nunca/raramente realizar actividad física/deportes $(\mathrm{RPa}=1,57)$, entre otros factores. Conclusión: Nunca/raramente despertarse descansado y realizar actividad física/deportes, la presencia de trastornos mentales comunes, síntomas osteomusculares y trastornos de la voz, están asociados a la insatisfacción con la salud.

Descriptores: Prevalencia; Salud Laboral; Maestros; Calidad de Vida; Salud. 


\section{INTRODUCTION}

The issue related to the health-disease process and the teachers' working conditions have been an increasing interest of researchers in the field of health and education ${ }^{(1)}$. Literature reviews on teacher's health have shown that these people are presenting a worrying physical and mental worsening condition ${ }^{(2)}$. As we have observed in the literature, there are frequent occurrences of reports from teachers' health problems, such as mental and behavioral disorders $^{(3-6)}$, voice disorders ${ }^{(7)}$ and complaints related to musculoskeletal disorders ${ }^{(3,6,8,9)}$. In a Brazilian capital, the number of teachers on a health treatment leave of absence was significant and the main causes were mental and behavioral disorders (depression, panic disorder, anxiety, mood disorder and Burnout Syndrome) and musculoskeletal system diseases (WRMD/RSI (Cumulative Trauma Disorders), tendinitis, arthrosis, arthritis and tenosynovitis) ${ }^{(10)}$.

Relationships between health status and work characteristics are complex and negatively affect teachers' ability to work ${ }^{(11)}$. A national survey carried out with this group found that around $70 \%$ rated their health as poor and very poor, stating they felt pressured to attend work when they had health problems ${ }^{(12)}$. Studies developed in the Brazilian cities Pelotas/RS ${ }^{(3)}$ and Bagé/RS ${ }^{(13)}$ showed that $18.9 \%$ and $14.3 \%$ of teachers rated their health as poor/regular. In Londrina/PR ${ }^{(14)}$ and in a nationwide survey ${ }^{(12)} 4.9 \%$ and $3.5 \%$ of teachers, respectively, considered their health as very poor or poor.

The assessment people make about their own health indicates, to some extent, their perception of their health condition and encompasses physical, emotional and cognitive components, aspects of well-being and satisfaction with their own lives ${ }^{(15,16)}$. The satisfaction or dissatisfaction levels refer to subjective evaluations, a result of individual comparisons and expectations, that is, a feeling of their $\mathrm{own}^{(17)}$. In this regard, health satisfaction research was incorporated into quality of life assessments proposed by the World Health Organization (WHO), considering elements linked to the subjectivity and multidimensionality of individuals, in a holistic health perspective resulting from multiple factors related to physical, mental and social well-being ${ }^{(18)}$.

Researches which investigate factors associated with health satisfaction are still scarce, for example, we found studies with rural populations ${ }^{(19)}$, adults who have been to a speech therapy linic $^{(15)}$ and none with teachers. In the investigations carried out with Brazilian teachers, there is evidence that they are dissatisfied with their health only through descriptive analyzes. In the city Viçosa-MG, a total of $10.9 \%$ of teachers said they were "very dissatisfied and dissatisfied" and $18.6 \%$ were indifferent, that is, "neither satisfied nor dissatisfied" in relation to health satisfaction ${ }^{(20)}$. In a study developed with teachers in the city of Florianópolis-SC, one in four participants was dissatisfied or very dissatisfied with their health ${ }^{(21)}$.

Health dissatisfaction levels indicate that something is not going well. In this regard, it is inferred the importance of nursing in health promotion actions, in order to work in collaboration with individuals, families and communities to create more favorable conditions for the expression of optimal health and high-levels of well-being ${ }^{(22)}$. Nurses have an important role in what is (or is not) developed in the places where they work and in the possibilities of opening new practices related to Public Health, especially if imbued with an expanded conception of the health-disease-care process ${ }^{(23)}$. We observed that the nursing performance related to teacher's health is still not enough when compared to research in speech therapy and psychology ${ }^{(2)}$. However, nursing has the potential to work intersectorally with schools, with managers and in care within its own territory (educational group activities, workers' health, care coordination within the attention network and in multi-professional actions).

Since little is known about the teachers' dissatisfaction with their health and also considering that the recognition of the factors associated with this outcome points to ways in supporting prevention and/or maintenance and health promotion actions, this investigation questioned the health dissatisfaction levels and the associated factors among teachers working in elementary school.

\section{OBJECTIVE}

To evaluate factors associated with health dissatisfaction of public elementary school teachers.

\section{METHODS}

\section{Ethical aspects}

This study was part of a matrix study entitled "Factors associated with the quality of life of elementary school teachers in public schools in Cuiabá-MT" approved by the Research Ethics Committee of the University Hospital Júlio Muller and meets the resolution of the National Health Council no 466/2012. The participants voluntarily contributed and signed the Free and Informed Consent Form.

\section{Design, study site and period}

This is a cross-sectional study carried out with elementary school teachers from the municipal public schools in Cuiabá, in the State of Mato Grosso, in Brazil. The data from the School Census indicated 75 schools with elementary education in the urban area and 1,317 teachers working in this education stage ${ }^{(24)}$. The data collection period happened between September and December, 2017.

\section{Population, sampling unit and sample; inclusion and exclusion criteria}

The population consisted of 1,317 teachers according to data from the School Census ${ }^{(24)}$ and the teacher was the sampling unit. To obtain the sample size, probabilistic sampling was used, thus, the simple random sampling method and the size of the population referred to were initially considered, with a proportion of $50 \%$, since the prevalence of the outcome was unknown, a $95 \%$ confidence interval $(z a / 2=1.96)$ and a sampling error of $5 \%$.

Thus, a minimum sample size of 298 teachers was estimated, with an increase of $35 \%$ for possible losses, totaling a final sample of 403 individuals. To estimate this increase, a survey conducted with teachers using a similar methodology was considered, which showed $40 \%$ of losses ${ }^{(21)}$, and the results of the current study's pilot test. 
Since this population was not evenly distributed among the administrative regional (North, South, East and West), it was also necessary to consider a stratified sample proportional to the size of these populations, in which the strata were constituted by these regionals. Subsequently, in each stratum, a random drawing of schools was carried out considering a systematic sampling procedure until we had obtained the number of teachers estimated in the respective stratum.

All elementary school teachers in the selected schools that were in full professional practice were included and those who were out of work, on leave or away from the classroom at the time of data collection were excluded.

\section{Study protocol}

All teachers from the selected schools that worked in elementary education (which include the stages from the $1^{\text {st }}$ to the $9^{\text {th }}$ grade) were invited to participate in the research by filling out the questionnaire, which was delivered by the main researcher on the date of the invitation and collected on the next day or up to two subsequent attempts, carried out at the workplace.

The self-administered questionnaire used was composed of a compilation of the following validated instruments: World Health Organization Quality Life-bref (WHOQOL-bref)(18), Vocal Production Condition - Teacher (CPV-P) ${ }^{(25,26)}$, Screening Index for Voice Disorder (SIVD) ${ }^{(27)}$, the Self-Reporting Questionnaire (SRQ-20) ${ }^{(28)}$ and the Nordic Musculoskeletal Questionnaire (NMQ) ${ }^{(29)}$ addition to some additional questions proposed on socioeconomic aspects and lifestyle habits.

With regard to the WHOQOL-bref instrument, which assesses quality of life, the outcome used in this study was only the measure: "How satisfied are you with your health?", whose answer can occur in five items of predefined categories ${ }^{(18)}$. Thus, the dependent variable was dichotomized into: Dissatisfied (comprising the items "neither satisfied/nor dissatisfied", "dissatisfied" and "very dissatisfied") and Satisfied ("satisfied" and "very satisfied").

The other instruments provided data related to the independent variables, which are described below:

1) Sociodemographic variables: the CPV-P instrument provided information regarding age, categorized into age groups ( $\geq 50$ years, $40-49$ years, 30-39 years, $\leq 29$ years); gender; marital status; schooling; and an additional question investigated how long it took them to commute (in categories, $<15$ minutes, 16 - 30 minutes, 31 - 60 minutes and more than 60 minutes).

2) Occupational variables: the CPV-P instrument, validated by experts ${ }^{(25,26)}$, provided information about the time in the profession ( $\geq 20$ years, $10-19$ years and $\leq 9$ years); number of schools they work (in 1 school, 2 or more schools); workload in contact with students ( $\geq 40$ hours, $21-40$ hours, $\leq 20$ hours); and employment bond (Temporary contract/Substitute or Continuing contract / with defined class).

2.1) Regarding the work environment, it was evaluated: Presence of noise; Satisfactory acoustics; Echo presence; Presence of dust; Presence of smoke; Nice temperature; Adequate air humidity; Adequate lighting; Satisfactory cleaning at school; Adequate hygiene in the bathrooms; Adequate room size; Furniture suitable for stature.
2.2) Regarding the organization and conditions of work: Adequate place for the teacher's rest; Freedom, planning and carrying out activities; Constant supervision; Stressful pace; Suitable material; Sufficient material; Monotonous work; Repetitive work; Time to carry out activities at school; Work that is performed at home; Ease of leaving the room; Intense physical effort; Carrying weight frequently; Employee commitment; Job satisfaction; Stress at work; Work interferes with health.

2.3) Situations of violence that are witnessed at school: Theft of personal items; Theft of school materials; Bullying manifestation; Fight among students; Violence against teachers and staff; Acts of vandalism against the building; Violence outside the school.

All occupational variables (item 2) were dichotomized into: "sometimes/always" and "never/rarely", for analysis purposes.

3) Life habits: the CPV-P instrument ${ }^{(25-26)}$ provided information regarding leisure activities; smoke; alcoholic beverages; eating at regular times; and an additional question investigated whether the participant engaged in physical activity or sports.

4) Sleep Aspects: Wakes up during the night; Wakes up rested; Hours of Sleep (categorized as $\leq 6$ hours and $\geq 7$ hours).

5) Health conditions: The information was self-reported and the occurrence of signs and symptoms suggestive of injuries were assessed by three validated instruments. The voice disorder was assessed using the SIVD instrument that investigated 12 vocal symptoms, being considered as voice disorders presence for those who referred "sometimes or always" to five or more items ${ }^{(27)}$.

Mental health conditions were assessed using the SQR-20 instrument, proposed by the World Health Organization (WHO), which investigates physical and psycho-emotional changes in 20 questions in order to screen for the presence of symptoms of common mental disorders (CMD). In this study, a cutoff point of $\leq$ 7 points (absent) and $\geq 8$ points (present) was adopted for CMD symptoms ${ }^{(30)}$. The occurrence of musculoskeletal symptoms was assessed in the last 12 months using the Nordic Musculoskeletal Questionnaire (NMQ) instrument, developed with the purpose of standardizing the measurement of the reporting of musculoskeletal symptoms from an anatomical figure, where the participants reported "yes" or "no" to the occurrence of these symptoms ${ }^{(9)}$. In this study, who answered "yes" was considered, regardless of the amount and the indicated body segment.

\section{Results and statistics analysis}

Descriptive analysis of data was performed considering absolute and relative frequencies and means and standard deviations. Associations between dependent and independent variables were verified in bivariate analyzes to obtain crude estimates of the prevalence ratio. The variables that presented $p$ values less than 0.20 in the bivariate analysis were introduced in the Poisson regression model with robust variance. In the final regression model, variables with a significance level lower than 0.05 remained, considering Wald's Chi-square hypothesis test and the likelihood ratio test to verify the adequacy of the model.

Health dissatisfaction was considered as the outcome and 4 models of analysis were proposed. The difference among these models, although with the same outcome, was the entry of the first independent variable in each model. In such a way, the 
inclusion of the other independent variables in all models was individually and in decreasing order of statistical significance. Thus, in the Model 1, the initial exposure was made from the symptom variable of CMD, in the Model 2 from the complaints of musculoskeletal symptoms and in the Model 3 from voice disorders. In the Model 4, all independent variables of the three health conditions evaluated were simultaneously introduced in this model. In the latter model (4) there was also a need to adjust it, considering the interaction between common mental disorder and musculoskeletal disorders in the last 12 months, as the interaction between these two variables was statistically significant.

The data obtained by the instruments were verified in double typing and the bases compared using the Epilnfo program. For data analysis, the statistical package SPSS was used.

\section{RESULTS}

403 questionnaires were delivered, 71 of which were not returned and 6 were incomplete, totaling 326 valid questionnaires. The total of valid questionnaires $(n=326)$ corresponded to approximately $81 \%$ coverage of the defined sample size.

The participants were, on average. 43.01 years old $(S D=9.31)$, with a predominance in the age group between $40-49$ years $(42.0 \%)$, female (87.12\%) and living with a spouse (62.70\%). Regarding the functional situation, $38.94 \%$ worked in the profession $\leq 9$ years, $58.95 \%$ worked in a single school, $45.28 \%$ remained in contact with students for $21-40$ hours and $54.60 \%$ had a professional relationship as a temporary contract/substitute teacher.

There was a prevalence of $53.07 \%$ of teachers with voice disorders, $29.75 \%$ with common mental disorder and $76.07 \%$ with complaints of musculoskeletal symptoms in the last 12 months. As for health satisfaction, most were satisfied (41.36\%), then $31.48 \%$ reported they were neither satisfied/nor dissatisfied, and $19.45 \%$ confirmed health dissatisfaction, as shown in Table 1.

Table 2 shows some independent variables with statistically significant associations between the dependent variable health dissatisfaction in a bivariate analysis. In addition to the associations shown in Table 2, there were also significant occurrence of noise at times/always (RP: $1.55 ; \mathrm{p}=0.005$ ) as an outcome; never/ rarely the room has satisfactory acoustics (RP: $1.28 ; p=0.025)$; the presence of echo in the classroom - sometimes/always (RP: 1.41; $\mathrm{p}=0.002)$; perceives the stressful rhythm - sometimes/always (RP: 1.58; $p=0.006)$; Intense physical effort - sometimes/always (RP: $1.26 ; p=0.041)$; Carries weight often/always (RP: $1.33 ; p=0.010$ ).

Table 3 shows analyzes of Poisson's multiple regression models for health dissatisfaction, based on the initial adjustment of the most frequent injuries among teachers. It was observed that health dissatisfaction remains significantly associated with factors such as never/rarely waking up rested, not doing physical activity or playing sports, not having time to perform activities at school and realizing that violence against teachers and staff often occurs (sometimes/always), both in the Model 1 that included association with CMD symptoms, and in the Model 2 with musculoskeletal complaints in the last 12 months.

In the Model 3, which illustrated the health dissatisfaction associated with the occurrence of voice disorders, factors such as never/rarely waking up rested, not doing physical activity or playing sports, not having time to perform activities at school, were also significantly associated, often realizing that there is an intense physical effort at work (sometimes/always) and time in the profession between 10-19 years of teaching.

Table 1 - Frequency of health satisfaction, sociodemographic characteristics, functional situation and health conditions of elementary school teachers. Cuiabá, Mato Grosso, Brazil, 2017

\begin{tabular}{|c|c|c|}
\hline Variable & $\mathbf{n}$ & $\%$ \\
\hline \multicolumn{3}{|l|}{ How satisfied are you with your health? } \\
\hline 1- Very dissatisfied & 8 & 2.47 \\
\hline 2- Dissatisfied & 55 & 16.98 \\
\hline 3- Neither satisfied nor dissatisfied & 102 & 31.48 \\
\hline 4- Satisfied & 134 & 41.36 \\
\hline 5- Very satisfied & 25 & 7.72 \\
\hline \multicolumn{3}{|l|}{ Sociodemographic } \\
\hline \multicolumn{3}{|l|}{ Gender } \\
\hline Female & 283 & 87.12 \\
\hline Male & 42 & 12.88 \\
\hline \multicolumn{3}{|l|}{ Age group } \\
\hline $21-29$ years & 27 & 8.28 \\
\hline $30-39$ years & 83 & 25.46 \\
\hline $40-49$ years & 137 & 42.02 \\
\hline $50-69$ years & 79 & 24.23 \\
\hline \multicolumn{3}{|l|}{ Marital status } \\
\hline With spouse (married or union) & 200 & 62.70 \\
\hline Without spouse (single, divorced, widowed) & 119 & 37.30 \\
\hline \multicolumn{3}{|l|}{ Health conditions } \\
\hline \multicolumn{3}{|l|}{ Time in the profession } \\
\hline$\leq 9$ years & 125 & 38.94 \\
\hline $10-19$ years & 94 & 29.28 \\
\hline$\geq 20$ years & 102 & 31.78 \\
\hline \multicolumn{3}{|l|}{ Number of schools you work } \\
\hline One school & 191 & 58.95 \\
\hline Two or more schools & 133 & 41.05 \\
\hline \multicolumn{3}{|l|}{ Weekly hours with students } \\
\hline$\leq 20$ hours & 134 & 42.14 \\
\hline $21-40$ hours & 144 & 45.28 \\
\hline$\geq 40$ hours & 40 & 12.58 \\
\hline \multicolumn{3}{|l|}{ Employment Bond } \\
\hline Continuing contract & 148 & 45.40 \\
\hline Temporary contract & 178 & 54.60 \\
\hline \multicolumn{3}{|l|}{ Health conditions } \\
\hline \multicolumn{3}{|l|}{ Common mental disorder } \\
\hline Present & 97 & 29.75 \\
\hline Absent & 229 & 70.25 \\
\hline \multicolumn{3}{|l|}{ Musculoskeletal symptoms (12 months) } \\
\hline Yes & 248 & 76.07 \\
\hline No & 78 & 23.93 \\
\hline \multicolumn{3}{|l|}{ Voice disorders } \\
\hline Present & 173 & 53.07 \\
\hline Absent & 153 & 46.93 \\
\hline
\end{tabular}

In the Model 4, it was shown that health dissatisfaction when associated with the occurrence of CMD symptoms, musculoskeletal symptoms in the last 12 months and Voice disorders, also maintained a significant association with factors such as never/ rarely waking up rested and not practicing physical activity or sports. However, in this model there was also an interaction variable between CMD symptoms and musculoskeletal disorders in the last 12 months, which was significant and with an adjusted prevalence ratio of $0.51(p<0,006)$. 
Table 2 - Bivariate analysis between sociodemographic and occupational variables, lifestyle, sleep and health conditions and health dissatisfaction among elementary school teachers, Cuiabá, Mato Grosso, Brazil, 2017

\begin{tabular}{|c|c|c|c|c|c|}
\hline \multirow[b]{2}{*}{ Variables } & \multicolumn{5}{|c|}{ Health Satisfaction } \\
\hline & Dissatisfied & Satisfied & Gross RP & IC(95\%) & $p$ \\
\hline \multicolumn{6}{|l|}{ Sociodemographic } \\
\hline \multicolumn{6}{|c|}{ Time commuting from home to work } \\
\hline$\geq 31 \mathrm{~min}$ & 33 & 22 & 1.38 & $1.04-1.82$ & 0.034 \\
\hline $16-30 \mathrm{~min}$. & 60 & 44 & 1.33 & $1.04-1.69$ & 0.024 \\
\hline$\leq 15 \mathrm{~min}$ & 70 & 91 & 1 & & \\
\hline \multicolumn{6}{|l|}{ Functional Situation } \\
\hline \multicolumn{6}{|l|}{ Time as a teacher } \\
\hline$\geq 20$ years & 52 & 48 & 1.18 & $0.89-1.55$ & 0.232 \\
\hline $10-19$ years & 57 & 37 & 1.38 & $1.07-1.78$ & 0.015 \\
\hline$\leq 9$ years & 55 & 70 & 1 & & \\
\hline \multicolumn{6}{|c|}{ Time to carry out activities at school } \\
\hline Never/rarely & 26 & 10 & 1.50 & $1.18-1.90$ & 0.007 \\
\hline Sometimes/always & 135 & 145 & 1 & & \\
\hline \multicolumn{6}{|l|}{ Work interferes on health } \\
\hline Sometimes/always & 133 & 102 & 1.66 & $1.20-2.28$ & $<0.001$ \\
\hline Never/rarely & 28 & 54 & 1 & & \\
\hline \multicolumn{6}{|c|}{ Violence against teachers and staff } \\
\hline Sometimes/always & 72 & 41 & 1.46 & $1.19-1.80$ & 0.001 \\
\hline Never/rarely & 88 & 114 & 1 & & \\
\hline \multicolumn{6}{|l|}{ Violence outside school } \\
\hline Sometimes/always & 76 & 54 & 1.28 & $1.03-1.58$ & 0.026 \\
\hline Never/rarely & 85 & 101 & 1 & & \\
\hline \multicolumn{6}{|l|}{ Life Habits } \\
\hline \multicolumn{6}{|l|}{ Leisure activities } \\
\hline Never/rarely & 60 & 34 & 1.38 & $1.12-1.71$ & 0.004 \\
\hline Sometimes/always & 101 & 118 & 1 & & \\
\hline \multicolumn{6}{|l|}{ Physical activity/sports } \\
\hline Never/rarely & 106 & 55 & 1.78 & $1.41-2.25$ & $<0.001$ \\
\hline Sometimes/always & 57 & 97 & 1 & & \\
\hline \multicolumn{6}{|l|}{ Eating at regular times } \\
\hline Never/rarely & 38 & 16 & 1.48 & $1.19-1.83$ & 0.002 \\
\hline Sometimes/always & 126 & 139 & 1 & & \\
\hline \multicolumn{6}{|l|}{ Sleep Aspect } \\
\hline \multicolumn{6}{|l|}{ Wake up at night } \\
\hline Sometimes/always & 130 & 105 & 1.35 & $1.02-1.79$ & 0.024 \\
\hline Never/rarely & 34 & 49 & 1 & & \\
\hline \multicolumn{6}{|l|}{ Wake up rested } \\
\hline Never/rarely & 68 & 18 & 1.92 & $1.58-2.32$ & $<0.001$ \\
\hline Sometimes/always & 92 & 131 & 1 & & \\
\hline \multicolumn{6}{|l|}{ Sleeping Hours } \\
\hline$\leq 6$ horas & 94 & 63 & 1.47 & $1.17-1.85$ & 0.001 \\
\hline$\geq 7$ horas & 62 & 90 & 1 & & \\
\hline \multicolumn{6}{|l|}{ Health Conditions } \\
\hline Common Mental Disor & & & & & \\
\hline Present & 73 & 23 & 1.88 & $1.55-2.29$ & $<0.001$ \\
\hline Absent & 92 & 136 & 1 & & \\
\hline Voice disorders & & & & & \\
\hline Present & 108 & 64 & 1.67 & $1.32-2.12$ & $<0.001$ \\
\hline Absent & 57 & 95 & 1 & & \\
\hline Musculoskeletal sympto & & & & & \\
\hline Yes & 141 & 105 & 1.86 & $1.31-2.64$ & $<0.001$ \\
\hline No & 24 & 54 & 1 & & \\
\hline
\end{tabular}

\section{DISCUSSION}

The relevance of this study lies in the fact that it presents an analysis of dissatisfaction with teachers' health in a multifactorial perspective. Thus, health dissatisfaction was associated with factors such as the lack of time to perform activities at school, the lack of physical activity/sports, low quality of sleep, the occurrence of common mental disorders, musculoskeletal complaints and voice disorders.

This is a sample of teachers, mostly female, with an average age of approximately 43 years. The general characteristics found in this study, such as the predominance of women, corroborated with other studies that involved teachers in this category and the data from the educational census ${ }^{(12,24)}$. Due to its gender related characteristic, as this job is usually performed by women, as it became evident in this group of workers, is the result of a historical social process of career construction ${ }^{(31)}$.

The percentage of teachers who expressed being dissatisfied or very dissatisfied with their health in this study was $19.45 \%$. When compared to French teachers who had dissatisfaction average close to $16 \%{ }^{(32)}$, the values found in this study were higher, however, among Brazilian studies developed in other regions, the levels ranged from $10.9 \%{ }^{(20)}$ to higher levels of $25.3 \%$ among teachers ${ }^{(21)}$. In all cases, these levels of dissatisfaction indicate the need for greater attention from professionals and managers to teachers' health.

In the present study, although prevalence of $29.75 \%$ was found for CMD, $76.07 \%$ for musculoskeletal complaints in the last 12 months and $53.07 \%$ for voice disorders, the levels of health dissatisfaction remained at percentage lower than these injuries. One possible explanation is that teachers had limitations in the perception of elements related to their own health condition $^{(13)}$. Sometimes, there is a resistance to talk about the disease and suffering, with a tendency to hide the illness or to disregard it until it appears due to more evident symptoms ${ }^{(33)}$. Among teachers, there seems to be 
Table 3 - Results of the Poisson regression analysis for factors associated with health dissatisfaction among elementary school teachers, Cuiabá, Mato Grosso, Brazil, 2017

\begin{tabular}{|c|c|c|c|c|c|c|c|c|}
\hline \multirow{3}{*}{ Variables } & \multicolumn{8}{|c|}{ Health dissatisfaction } \\
\hline & \multicolumn{2}{|l|}{ Model 1} & \multicolumn{2}{|l|}{ Model 2} & \multicolumn{2}{|l|}{ Model 3} & \multicolumn{2}{|l|}{ Model 4* } \\
\hline & $\mathbf{R P}_{\text {adjusted }}(\mathrm{IC95 \% )}$ & $\begin{array}{c}p \\
\text { value }\end{array}$ & $\mathbf{R P}_{\text {adjusted }}($ IC95\%) & $\begin{array}{c}p \\
\text { value }\end{array}$ & $\mathbf{R P}_{\text {adjusted }}($ IC95\%) & $\begin{array}{c}p \\
\text { value }\end{array}$ & $\mathbf{R P}_{\text {adjusted }}(\mathrm{IC} 95 \%)$ & $\begin{array}{c}p \\
\text { value }\end{array}$ \\
\hline Common mental disorders & $1.42(1.16-1.74)$ & $<0.001$ & - & - & - & - & $2.28(1.43-3.64)$ & 0.001 \\
\hline Musculoskeletal symptoms in the last 12 months & - & - & $1.60(1.16-2.22)$ & 0.004 & - & - & $1.71(1.15-2.53)$ & 0.008 \\
\hline Voice disorders & - & - & - & - & $1.34(1.07-1.68)$ & 0.010 & $1.29(1.01-1.63)$ & 0.037 \\
\hline $\begin{array}{l}\text { Sleep: Wake up rested } \\
\text { Never/rarely }\end{array}$ & $1.45(1.18-1.78)$ & $<0.001$ & $1.57(1.28-1.92)$ & $<0.001$ & $1.62(1.33-1.96)$ & $<0.001$ & $1.45(1.18-1.78)$ & $<0.001$ \\
\hline $\begin{array}{l}\text { Physical activity or sports } \\
\text { Never/rarely }\end{array}$ & $1.58(1.23-2.01)$ & $<0.001$ & $1.64(1.29-2.08)$ & $<0.001$ & $1.63(1.29-2.07)$ & $<0.001$ & $1.57(1.25-1.98)$ & $<0.001$ \\
\hline $\begin{array}{l}\text { Time to carry out activities at school } \\
\text { Never/rarely }\end{array}$ & $1.30(1.03-1.63)$ & 0.024 & $1.29(1.04-1.62)$ & 0.023 & $1.33(1.07-1.66)$ & 0.011 & - & - \\
\hline $\begin{array}{l}\text { Violence against teachers and staff } \\
\text { Sometimes/always }\end{array}$ & $1.28(1.05-1.56)$ & 0.014 & $1.29(1.06-1.58)$ & 0.010 & - & - & - & - \\
\hline $\begin{array}{l}\text { Intense physical effort at work } \\
\text { Sometimes/always }\end{array}$ & - & - & - & - & $1.28(1.06-1.56)$ & 0.012 & - & - \\
\hline \multicolumn{9}{|l|}{ Time in the profession } \\
\hline$\geq 20$ years & - & - & - & - & $1.24(0.965-1.59)$ & 0.093 & - & - \\
\hline 10-19 years & - & - & - & - & $1.29(1.01-1.64)$ & 0.040 & - & - \\
\hline$\leq 9$ years & - & - & - & - & 1.00 & - & - & - \\
\hline
\end{tabular}

Notes: Model 1 - Sociodemographic, occupational, lifestyle, sleep and Common Mental Disorder (CMD) variables. Model 2 - Sociodemographic, occupational variables, lifestyle, sleep and musculoskeletal symptoms 12 months. Model 3 - Sociodemographic, occupational variables, lifestyle, sleep and Voice Disorders. Model 4 - Sociodemographic and occupational variables, life habits, sleep, $C M D$, Musculoskeletal Symptoms 12 months and Voice Disorders. * adjusted by the interaction variable between CMD and musculoskeletal disorders in the last 12 months, (RP ${ }_{\text {adjusted }}=0,51 ; p_{<0,006)}$.

a cultural naturalization of malaise and problems, sufferings and illnesses, giving rise to a possible extension of the time of suffering and consequently delay in seeking professional help ${ }^{(1)}$. Thus, paying more attention to teachers' health conditions is necessary, which will not always be manifested beforehand, in levels of dissatisfaction.

In this study, the occurrence of common mental disorder, musculoskeletal complaints and complaints of voice disorders were associated with health dissatisfaction. As far as it is known, there are no studies that show these diseases specifically associated with the outcome. However, a research with teachers from a city in the southern region of Brazil, found that the perception of health was associated with the level of stress, arterial hypertension, among other factors ${ }^{(13)}$. Furthermore, the presence of chronic morbidity was associated with poor self-rated health, as well as having an impact on the way the individual assessed his own health ${ }^{(16,34)}$.

It was observed that the strength of the association between the signs of CMD and health dissatisfaction stood out in the model (4), as it presented a higher adjusted prevalence ratio than the other variables considered in this model. However, to date, no studies have been found associating these two factors. Nevertheless, some previous studies with teachers already indicated that aspects related to mental disorders were associated with other variables ${ }^{(5,35)}$, which suggests greater attention to the psycho-emotional conditions of these workers.

It was also observed, in model 4, the existence of an interaction between CMD and the complaint of musculoskeletal disorders in the last 12 months. The interaction between these two conditions cannot be considered to have a protective effect on health dissatisfaction, even though, the prevalence ratio was less than one. Possibly, this result would reflect the lack of health dissatisfaction in these professionals, however, further research would be necessary to clarify this interaction. In this regard, it is noted that sometimes it can be difficult for the teacher to recognize his own body, feeling of malaise, suffering and illness at work ${ }^{(1)}$.

The perception that the intense physical effort at work occurred sometimes/always and the time in the profession between 10-19 years was associated with health dissatisfaction in the model adjusted for the occurrence of vocal disorders. Literature has also revealed that among the multiple factors associated with the teacher's vocal alteration, teaching time greater than and equal to five years ${ }^{(7)}$; and the intense physical effort at work contributed to the dysphonia in these professionals ${ }^{(36)}$. These findings reinforce greater attention to the elements of work and its effects on health.

In this study, violence against teachers and staff was frequent and was associated with health dissatisfaction in the models adjusted for the occurrence of common mental disorders and complaints of musculoskeletal disorder. Previous studies have also indicated that situations of violence at school, such as threats, verbal and physical aggression against the teacher were associated with cases of $\mathrm{CMD}^{(4)}$ and worse levels of depersonalization in the Burnout Syndrome ${ }^{(37)}$. In a survey with teachers from Pernambuco, the student was most frequently identified as the main perpetrator of cases of verbal and physical violence ${ }^{(4)}$. Another study 
pointed out that labor factors, such as hostile work environment, a high number of students and suffering violence, cooperate so that work stress becomes chronic and progresses to Burnout Syndrome, and it is necessary to recognize these realities and also promote public measures to ensure appropriate conditions in the workplace which can improve the quality of life of teachers and the physical and psychological health maintenance ${ }^{(37)}$.

It was observed in the study that there is an association of elements related both to life habits (never/rarely practiced physical activity and/or sports) and to the functional situation (never/ rarely had time to carry out activities at school) influencing their levels of health dissatisfaction. The influence of physical activity on health perception was evidenced in other studies and also among teachers ${ }^{(13,16,34)}$. Physical activity, both during leisure and during five or more days per week, was identified as a potential protective factor for problems in the teaching because of the voice ${ }^{(38)}$. However, failure to perform or the inadequate practice of physical activity among teachers was a factor associated with the occurrence of $\mathrm{CMD}^{(6)}$; and the presence of musculoskeletal symptoms in the last 12 months $^{(9)}$. It is observed that the way the work of the public school teacher is structured can hinder the practice of physical activity, but even so, it is possible to indicate actions of promotion considering the factors of the work ${ }^{(14)}$. The WHO recommendations for physical activity are that over a week, at least 150 minutes should be performed at moderate intensity or 75 minutes at a vigorous intensity ${ }^{(39)}$.

Regarding sleep aspects, it was found that the variable never/ rarely waking up rested was associated with health dissatisfaction in all models. Initially, in a bivariate analysis, the duration of sleep was associated with health dissatisfaction, however, this association was not supported by the multiple models, remaining only aspects related to the quality of sleep (waking up rested). Among teachers, poor sleep quality was a frequent complaint ${ }^{(40)}$, and elements such as sleep problems, use of anxiolytic drugs, and occupational diseases were directly linked to health status ${ }^{(11)}$. Evaluation of sleep quality and mental health among teachers is recommended, as well as interventions that consider stress counseling and management ${ }^{(40)}$. Since situations involving problems related to sleep can compromise health, quality of life, in addition to affecting the ability to work ${ }^{(11)}$.

\section{Study limitations}

The present study had limitations inherent to the crosssectional design. Thus, it was not possible to trace the cause and effect relationship of the investigated elements in a temporal sequence. The fact that the study was carried out with teachers in effective exercise during the period of data collection could also create the so-called "healthy worker effect" and, therefore, not include teachers who were removed from the activity due to health problems. However, this does not mean that the teachers who are working are not necessarily sick, as it is known that many workers, for various reasons, continue to work, even without good health conditions. Another important limitation refers to the scarcity of studies that assessed health dissatisfaction.

\section{Contributions to the field of nursing, health or public policy}

As contributions, the study can support health and nursing professionals to identify factors associated with teachers' health dissatisfaction, directing the planning of individual and collective assistance. The authors were able to observe, from the results found and from the revised literature that, sometimes, in teachers, health dissatisfaction will not be manifested directly and for this reason, nurses are recommended to open new health practices aimed at prevention and promotion of health. Furthermore, the findings may also collaborate to mobilize public policies, since it presents an alert to professionals, managers and society as to the health condition of public-school teachers.

\section{CONCLUSION}

It became evident that the factors associated with teachers' health dissatisfaction are linked to occupational aspects, in this case, the lack of time to carry out activities at school, and to individual aspects such as not performing physical activity/ sports, low quality of sleep (assessed by the variable never/rarely wake up rested), the occurrence of common mental disorders, complaints of musculoskeletal symptoms in the last 12 months and voice disorders.

In addition to the factors mentioned above, other elements related to the environment and work organization were also associated with the dissatisfaction depending on the associated health condition. Thus, in the models in which there was an association between the presence of CMD and musculoskeletal complaints, there was also an association between the perception of violence against teachers and staff, significantly affecting health dissatisfaction. In the explanatory model for the occurrence of health dissatisfaction associated with voice disorders, factors such as the perception of intense physical effort at work and the time in the profession between 10 and 19 years were significantly associated.

\section{REFERENCES}

1. Penteado RZ, Souza Neto S. Teacher malaise, suffering and sickness: from narratives of teacher work and culture to teaching as a profession. Saúde Soc, São Paulo. 2019;28(1):135-53. doi: 10.1590/S0104-12902019180304

2. Cortez PF, Souza MVR, Amaral LO, Silva LCA. A saúde docente no trabalho: apontamentos a partir da literatura recente. Cad Saúde Colet. 2017;25(1):113-22. doi: 10.1590/1414-462×201700010001

3. Silva LG, Silva MC. Condições de trabalho e saúde de professores pré-escolares da rede pública de ensino de Pelotas, RS, Brasil. Ciên Saúde Coletiva. 2013;18(11):3137-46. doi: 10.1590/S1413-81232013001100004 
Factors associated with health dissatisfaction of elementary school teachers Santos EC, Espinosa MM, Marcon SR, Reiners AAO, Valim MD, Alves BMM.

4. Lima AFT, Coêlho VMS, Ceballos AGC. Violência na escola e transtornos mentais comuns em professores. Rev Port Enferm Saúde Mental. 2017;18:31-36. doi: 10.19131/rpesm.0189

5. Ceballos AGC, Santos GB Factors associated with musculoskeletal pain among teachers: sociodemographics aspects, general health and well-being at work. Rev Bras Epidemiol. 2015;18(3):702-15. doi: 10.1590/1980-5497201500030015

6. Baldaçara L, Silva ÁF, Castro JGD, Santos GCA. Common psychiatric symptoms among public school teachers in Palmas, Tocantins, Brazil. An observational cross-sectional study. Sao Paulo Med J. 2015;133(5):435-8. doi: 10.1590/1516-3180.2014.8242810

7. Ministério da Saúde (BR). Departamento de Vigilância em Saúde Ambiental e Saúde do Trabalhador. Distúrbio de Voz Relacionado ao Trabalho (DVRT). Saúde do Trabalhador: Protocolos de Complexidade Diferenciada[Internet]; n. 11. Brasília: Ministério da Saúde; 2018 [cited 2019 Jun 16]. 42p. Available from: http://bvsms.saude.gov.br/bvs/publicacoes/disturbio_voz_relacionado_trabalho_dvrt.pdf

8. Jesus CS, Carvalho FM, Araújo TM. Demanda psicológica no trabalho e dor musculoesquelética em professoras. Psicol Saúde Doenças. 2016;17(3):575-86. doi: 10.15309/16psd170320

9. Fernandes MH, Rocha VMD, Oliveira AGRC. Fatores Associados à Prevalência de Sintomas Osteomusculares em Professores. Rev Salud Pública[Internet]. 2009 [cited 2019 Aug 31];11(2):256-67. Available from: https://www.scielosp.org/article/rsap/2009.v11n2/256-267/

10. Tribunal de Contas do Estado de Mato Grosso TCE/MT. Relatório de auditoria operacional: concessão de licenças médicas e absenteísmo de professores do ensino fundamental em Cuiabá e Várzea Grande 2017 [Internet]. Cuiabá: PubliContas, 2018 [cited 2019 Aug 10]. 32 p. Available from: https://www.tce.mt.gov.br/uploads/flipbook/RAOLicMedProfCbaVG2017/index.html

11. Alcântara MA, Medeiros AM, Claro RM, Vieira MT. Determinants of teachers' work ability in basic education in Brazil: educatel study, 2016. Cad Saúde Pública. 2019;35(Suppl 1):e00179617. doi: 10.1590/0102-311x00179617

12. Assunção AA, Abreu MNS. Pressure to work, health status, and work conditions of schoolteachers in Basic Education in Brazil. Cad Saúde Pública. 2019;35(Sup.1):e00189617. doi: 10.1590/0102-311X00169517

13. Santos MN, Marques AC. Condições de saúde, estilo de vida e características de trabalho de professores de uma cidade do sul do Brasil. Ciênc Saúde Coletiva 2013;18(3):837-846. doi:10.1590/S1413-81232013000300029

14. Dias DF, Loch MR, González AD, Andrade SM, Mesas AE. Insufficient free-time physical activity and occupational factors in Brazilian public school teachers. Rev Saude Publica. 2017;51:68, 10p. doi: 10.1590/S1518-8787.20170510062171

15. Azevedo GPGC, Friche AAL, Lemos SMA. Quality of life and self-perception of health of patients from an Outpatient Clinic of SpeechLanguage Pathology and Audiology. Rev Soc Bras Fonoaudiol. 2012;17(2):119-27. doi: 10.1590/S1516-80342012000200004

16. Pavão ALB, Werneck GL, Campos MR. Autoavaliação do estado de saúde e a associação com fatores sociodemográficos, hábitos de vida e morbidade na população: um inquérito nacional. Cad Saúde Pública. 2013;29(4):723-734. doi: 10.1590/S0102-311X2013000400010

17. Bowling A. Part 1. A taxonomy and overview of quality of life [Internet]. In: Brown J, Bowling A, Flynn T. Models of Quality of Life: A Taxonomy, Overview and Systematic Review of the Literature 2004 [cited 2019 Aug 10]. European Forum on Population Ageing Research. p. 6-77. Available from: https://lemosandcrane.co.uk/resources/European\%20Forum\%20on\%20Population\%20Ageing\%20Research\%20-\%20 Models\%20of\%20Quality\%20of\%20Life.pdf

18. WHO- World Health Organization. Programme on mental health: WHOQOL user manual, 2012 revision[Internet]. 2012 [cited 2018 Jun 20]. Available from: http://www.who.int/iris/handle/10665/77932

19. Bortolotto CC, Loret, Mola C, Tovo-Rodrigues L. Qualidade de vida em adultos de zona rural no Sul do Brasil: estudo de base populacional. Rev Saude Publica. 2018;52 Supl 1:4s. doi: 10.11606/S1518-8787.2018052000261

20. Tavares DDF, Oliveira RAR, Mota Jr RJ, Oliveira CEP, Marins JCB. Quality of life of basic education teachers of public schools [Internet]. Rev Bras Promoç Saúde [cited 2019 Aug 31];2015;28(2):191-7. Available from: https://periodicos.unifor.br/RBPS/article/view/3448

21. Pereira ÉF, Teixeira CS, Lopes AS. Qualidade de vida de professores de educação básica do município de Florianópolis, SC, Brasil. Ciênc Saúde Coletiva. 2013;18(7):1963-70. doi:10.1590/S1413-81232013000700011

22. Pender NJ. Health Promotion Model Manual [Internet]. 2011 [cited 2019 Sep 01]. University of Michigan: Deep Blue. Available from: https:// deepblue.lib.umich.edu/bitstream/handle/2027.42/85350/HEALTH_PROMOTION_MANUAL_Rev_5-2011.pdf

23. Fortuna CM, Matumoto S, Mishima SM, Rodríguez AMMM. Enfermagem em Saúde Coletiva: desejos e práticas. Rev Bras Enferm. 2019;72(1):336-40. doi: 10.1590/0034-7167-2017-0632

24. Instituto Nacional de Estudos de Pesquisas Educacionais Anísio Teixeira (INEP). Sinopses Estatísticas da Educação Básica[Internet]. 2018 [cited 2018 Sep 25]. Available from: http://inep.gov.br/web/guest/sinopses-estatisticas-da-educacao-basica

25. Ferreira LP, Giannini SPP, Latorre MRDO, Zenari MS. Distúrbio da voz relacionado ao trabalho: proposta de um instrumento para avaliação de professores. Dist Comum[Internet]. 2007 [cited 2019 Sep 01];19(1):127-37. Available from: https://revistas.pucsp.br/dic/article/view/11884/8601

26. Giannini SPP, Latorre MDRDD, Ferreira LP. Condition of Vocal Production-Teacher questionnaire: comparison of responses on Likert scale and visual analog scale. CoDAS. 2016;28(1):53-8. doi: 10.1590/2317-1782/20162015030

27. Ghirardi ACA, Ferreira LP;Giannini SPP;Latorre MRDO. Screening Index for Voice Disorder (SIVD): development and validation. J Voice. 2013;27(2):195-200. doi: 10.1016/j.jvoice.2012.11.004

28. World Health Organization .WHO. Division of Mental Health. User's guide to self-reporting questionnaire (SRQ). Geneva: World Health Organization; 1994. 
29. Pinheiro FA, Tróccoli BT, Carvalho CV. Validação do Questionário Nórdico de Sintomas Osteomusculares como medida de morbidade. Rev Saúde Pública. 2002;36(3):307-12. doi: 10.1590/\$0034-89102002000300008

30. Gonçalves DM, Stein AT, Kapczinski F. Avaliação de desempenho do Self-Reporting Questionnaire como instrumento de rastreamento psiquiátrico: um estudo comparativo com o Structured Clinical Interview for DSM-IV-TR, 2007. Cad Saúde Pública. 2008;24(2):380-90. doi: 10.1590/S0102-311X2008000200017

31. Neves MYR, Brito JC, Muniz HP. Women schoolteachers' health, gender issues, and work in elementary education. Cad Saúde Pública. 2019;35(Sup.1):e00189617. doi: 10.1590/0102-311×00189617

32. Zavidovique L, Gilbert F, Vercambre-Jacquot MN. Bien-être au travail et qualité de vie des enseignants : quelles différences selon l'ancienneté? Archives des Maladies Professionnelles et de l'Environnement. 2018;79:105-19. doi: 10.1016/j.admp.2017.09.005

33. Dejours C. A loucura do trabalho: estudo de psicopatologia do trabalho. 5. ed. São Paulo: Cortez, 1992.

34. Petarli GB, Salaroli LB, Bissoli NS, Zandonade E. Autoavaliação do estado de saúde e fatores associados: um estudo em trabalhadores bancários. Cad Saúde Pública. 2015;31(4):787-99. doi: 10.1590/0102-311X00083114

35. Casella JGC, Afonso MLM. Qualidade de vida docente: relação entre alterações psicoemocionais e disfonias. Rev Pedag. 2018;20(43):168-82. doi: 10.22196/rp.v20i43.3844

36. Ferreira LP, Giannini SPP, Figueira S, Silva EE, Karman DF, Thomé-de-Sousa TM. Condições de produção vocal de professores da Rede do Município de São Paulo. Disturb Comun. 2003;14(2):275-307.

37. Koga GKC, Melanda FN, Santos HG, Sant'Anna FL, González AD, Mesas AE, et al. Fatores associados a piores níveis na escala de Burnout em professores da educação básica. Cad Saúde Colet. 2015;23(3):268-75. doi: 10.1590/1414-462X201500030121

38. Santos SMM, Maia EG, Claro RM, Medeiros AM. Limitation of the use of voice in teaching and leisure-time physical activity: Educatel Study, Brazil, 2015/2016. Cad Saúde Pública. 2019;35(Supl.1):e00188317. doi: 10.1590/0102-311x00188317

39. World Health Organization-WHO. Global Recommendations on Physical Activity for Health: 18-64 years old.[Internet] Genebra 2011[cited 2019 Nov 17]. Available from: https://www.who.int/dietphysicalactivity/publications/recommendations18_64yearsold/en/

40. Musa NA, Moy FM, Wong LP. Prevalence and factors associated with poor sleep quality among secondary school teachers in a developing country. Industrial Health. 2018;56(5):407-18. doi: 10.2486/indhealth.2018-0052 